\title{
PENGARUH KOMPOSISI ARANG SEKAM PADI DAN ARANG KULIT BIJI JARAK PAGAR TERHADAP MUTU BRIKET ARANG
}

\section{The Effect of Rice Husks and Jatropha Seed Husks Composition on Briquette Quality}

\author{
Nilma Yuliza, Novizar Nazir*, Masrul Djalal \\ Fakultas Teknologi Pertanian, Kampus Limau Manis-Padang 25163, \\ *email: nazirnnovizar@yahoo.com
}

Diterima: 18 Februari 2013, Disetujui: 30 April 2013

\begin{abstract}
ABSTRAK
Briket arang merupakan bahan bakar yang berasal dari biomassa. Biomassa yang digunakan dalam penelitian ini adalah sekam padi dan kulit biji jarak pagar dengan pemakaian perekat $5 \%$ dari berat arang. Briket arang adalah arang yang diolah lebih lanjut menjadi bentuk briket yang dapat digunakan untuk keperluan energi sehari-hari. Briket yang terbuat dari kulit biji jarak pagar lebih tinggi di dalam kerapatan dan keteguhan tekan, tetapi lebih rendah di dalam kadar air, karbon terikat dan nilai kalor. Sedangkan briket yang terbuat dari sekam padi memiliki nilai kalor yang cukup tinggi dan mudah terbakar, tetapi lebih rendah di dalam kerapatan dan keteguhan tekan. Penelitian ini bertujuan untuk mengetahui pengaruh perbedaan tingkat perbandingan komposisi arang sekam padi dengan arang kulit biji jarak pagar terhadap mutu briket arang yang dihasilkan dan mendapatkan komposisi terbaik dalam pembuatan briket arang berdasarkan SNI 01-6235-2000 briket arang kayu. Rancangan yang digunakan adalah Rancangan Acak Lengkap (RAL) dengan 4 perlakuan dan 3 ulangan, dengan perlakuan tingkat perbandingan komposisi arang kulit biji jarak pagar dengan arang sekam padi sebanyak $30 \%: 70 \%, 25 \%: 75 \%$, 20\%:80\%, dan 15\%:85\%. Masing-masing produk tersebut kemudian dilakukan analisa kimia dan fisik. Data hasil penelitian dianalisis menggunakan uji $\mathrm{F}$ kemudian dilanjutkan dengan uji Duncan's New Multiple Range Test (DNMRT) pada taraf nyata 5\%. Hasil penelitian ini menunjukkan bahwa komposisi bahan pembuat briket arang memberikan pengaruh yang nyata terhadap kadar air, kadar abu, kualitas nilai kalor, volatile matter, fixed carbon, kerapatan dan kekuatan tekan serta laju pembakaran. Rata-rata nilai kadar abu, kualitas nilai kalor, volatile matter dan kerapatan belum memenuhi SNI 01-6235-2000 briket arang kayu. Sedangkan ratarata nilai kadar air, fixed carbon, kekuatan tekan memenuhi SNI 01-6235-2000 briket arang kayu. Hasil penelitian menunjukkan bahwa briket arang yang terbaik adalah pada perlakuan 30\%:70\% dengan nilai kalor $3906,27 \mathrm{kal} / \mathrm{gram}$.
\end{abstract}

\section{Kata Kunci: Briket arang, sekam, jarak pagar, kalor, energi}

\section{ABSTRACT}

Briquette is a fuel derived from biomass. Biomass used in this study were rice husks and Jatropha seed husks. Adhesives are materials which are used to provide adhesion to the briquettes. Adhesives used was $5 \%$ of the weight of charcoal. Briquettes are made from jatropha seed husks is higher in density and compressing strength, but lower in the water content, carbon and calorific value. While briquettes made from rice husk has a high calorific value and flammable, but lower in density and compressing strength. The purpose of this study to determine the effect of different composition levels of rice husk and jatropha seeds husks to briquettes quality according to Indonesian National Standard SNI 01-6235-2000 for briquettes. The design used was Completely Randomized Design (RCD), with 4 treatments and 3 replications. In this study, the composition of jatropha seeds husks and rice husk were as follow: 30\%: 70\%; 25\%: $75 \% ; 20 \%: 80 \%$; and 15\%: $85 \%$. Each product was then analyzed chemically and physically. Data were analyzed using the F test followed by a test of Duncan's New Multiple Range Test (DNMRT) on the significant level of 5\%. The results of this study indicated that the composition of the material for briquettes were significantly effect on moisture content, ash 
content, heating value, volatile matter, fixed carbon, density and compressive strength as well as the combustion rate. The average value of ash content, heating value quality, volatile matter and the density of the wood yet meet the SNI 01-6235-2000 for briquette. While the average value of moisture content, fixed carbon, compressing strength meet SNI 01-6235-2000 standard for briquettes. The results showed that the best briquette was the composition treatment of $30 \%$ : $70 \%$ (30\% of jatropha seed husks: $70 \%$ of rice husks) with a calorific value of $3906.27 \mathrm{cal} / \mathrm{g}$.

\section{Key words : Briquette, rice husk, jatropha, calor, energy}

\section{PENDAHULUAN}

Energi merupakan komponen utama bagi seluruh kegiatan makhluk hidup di bumi. Sumber energi utama bagi manusia adalah sumber daya alam yang berasal dari fosil karbon. Prediksi produksi minyak Indonesia menurut Kementerian Energi dan Sumber Daya Mineral (ESDM ) tahun 2010, akan mengalami kelangkaan yang sangat ekstrim 5-10 tahun lagi. Kementerian ESDM juga menyebutkan bahwa produksi energi fosil di Indonesia mengalami penurunan setiap tahun (Working Group Bidang Energi, 2008).

Kelangkaan energi akan lebih terasa lagi pada masa mendatang dan pada saat ini pun telah terlihat bahwa adanya gejala ketidakseimbangan antara permintaan dan penyediaan energi. Kelangkaan dan kenaikan harga minyak akan terus terjadi karena sifatnya yang nonrenewable. Hal ini harus segera diimbangi dengan penyediaan sumber energi alternatif yang renewable, melimpah jumlahnya dan murah harganya sehingga terjangkau oleh masyarakat luas. Usaha manusia dalam mencari sumber energi pengganti ini harus didasarkan pada bahan bakunya yang mudah diperoleh dan diperbaharui serta produknya mudah digunakan (Ndraha, 2010).

Dalam Peraturan Presiden Republik Indonesia Nomor 5 Tahun 2006 Tentang Kebijakan Energi Nasional dirumuskan bahwa perlu adanya peningkatan pemanfaatan sumber energi baru dan sumber energi terbarukan. Sasaran Kebijakan Energi Nasional adalah tercapainya elastisitas energi dan terwujudnya energy mix yang optimal meliputi penggunaan minyak bumi menjadi kurang dari 20\% (Syamsiro dan Saptoadi, 2007).
Salah satu komoditas pertanian yang potensial saat ini untuk dijadikan bahan bakar nabati diantaranya jarak pagar. Tanaman jarak pagar dapat dipilih karena tanaman ini tidak bersaing dengan tanaman penghasil pangan, tidak dimakan binatang karena beracun, mudah beradaptasi di lapangan, berpotensi menjadi bisnis baru untuk masyarakat dan kegiatan produksinya dapat lebih terdesentralisasi (Syakir, 2010).

Pengembangan tanaman jarak pagar (Jatropha curcas L.) sebagai bahan bakar alternatif mempunyai potensi yang sangat besar, selain menghasilkan minyak dengan produktivitas tinggi, dapat juga dijadikan bahan untuk pembuatan briket (Budiman dkk, 2010).

Pengolahan jarak pagar hanya terfokus pada pengolahan isi bijinya, sedangkan kulitnya menjadi limbah yang kurang termanfaatkan. Kulit biji jarak pagar dapat digunakan sebagai sumber energi untuk dijadikan briket, karena mengandung jumlah energi sebesar 19,3 - 19,5 MJ kg-1 (Syah, 2006).

Alternatif bahan baku briket lainnya adalah sekam padi. Sekam padi terdapat dalam jumlah yang melimpah, murah, dan terbarukan. Data Biro Pusat Statistik tahun 2011 menunjukkan bahwa produksi padi di Indonesia sekitar 67,31 juta ton per tahun. Total potensi sekam di Indonesia mencapai 16 juta ton per tahun (Badan Pusat Statistik, 2011).

Sekam memiliki kerapatan jenis 125 $\mathrm{kg} / \mathrm{m}^{3}$, dengan nilai kalori $1 \mathrm{~kg}$ sekam padi sebesar 3300 kkal dan ditinjau dari komposisi kimiawi, sekam mengandung karbon $1,33 \%$, hidrogen $1,54 \%$, oksigen $33,645 \%$ dan silika $\left(\mathrm{SiO}_{2}\right) 16,98 \%$, artinya sekam berpotensi dimanfaatkan sebagai bahan baku industri kimia dan sebagai sumber energi panas untuk keperluan manusia (Sipahutar, 2011).

Salah satu kelemahan sekam bila digu- 
nakan langsung sebagai sumber energi panas adalah menimbulkan asap pada saat dibakar. Hal ini mengakibatkan bahan yang dikeringkan berbau asap dan warna bahan berubah sehingga menurunkan kualitas bahan di samping menimbulkan polusi udara (Nugraha dan Setiawati, 2001).

Briket yang terbuat dari kulit biji jarak pagar lebih tinggi didalam kerapatan dan keteguhan tekan, tetapi lebih rendah didalam kadar air, karbon terikat dan nilai kalor (Sudradjat, Setiawan dan Roliadi, 2005). Sedangkan briket yang terbuat dari sekam padi memiliki nilai kalor yang cukup tinggi dan mudah terbakar, tetapi lebih rendah didalam kerapatan dan keteguhan tekan (Hermawan, 2005). Untuk menghasilkan briket yang lebih baik dilakukanlah penelitian dengan mencampur kedua bahan ini.

\section{METODOLOGI PENELITIAN}

\section{Bahan dan Alat}

Bahan-bahan yang digunakan dalam penelitian ini adalah kulit biji jarak pagar, sekam padi, tepung kanji, air dan oksigen. Sedangkan alat-alat yang digunakan adalah alat pengepres briket dengan tekanan 100 $\mathrm{N} / \mathrm{cm}^{2}$, cetakan yang berdiameter $2 \mathrm{~cm}$ dan tinggi $3 \mathrm{~cm}$, tabung pengarangan, ayakan 50 mesh, oven, timbangan digital, force gauge, thermometer, stopwatch, desikator, oxygen bomb calorimeter.

\section{Rancangan Penelitian}

Rancangan yang digunakan adalah Rancangan Acak Lengkap (RAL) dengan 4 perlakuan dan 3 ulangan, dengan perlakuan tingkat perbandingan komposisi arang kulit biji jarak pagar dengan arang sekam padi sebanyak 30\%:70\%, 25\%:75\%, 20\%:80\%, dan 15\%:85\%. Masing-masing produk tersebut kemudian dilakukan analisa kimia dan fisik. Data hasil penelitian dianalisis menggunakan uji $\mathrm{F}$ kemudian dilanjutkan dengan uji Duncan's New Multiple Range Test (DNMRT) pada taraf nyata $5 \%$.

\section{Pelaksanaan Penelitian}

Bahan baku yang disiapkan adalah kulit biji jarak pagar dan sekam padi. Bahan tersebut dikumpulkan dan dibersihkan dari material-material yang tidak berguna.

Kulit biji jarak pagar dan sekam padi dikeringkan di bawah sinar matahari, kemudian kadar air kedua bahan baku dianalisis terlebih dahulu sebelum dilakukan pengarangan. Kadar air sekam padi dan kulit biji jarak pagar maksimal 12\% (Hendra, 1999).

Kulit kering biji jarak pagar dan sekam padi diarangkan secara terpisah. Sementara pengecilan ukuran dilakukan dengan menumbuk bahan dengan lumpang dan alu. Bahan yang telah ditumbuk diayak dengan ayakan 50 mesh. Pemilihan ukuran pengayakan pada penelitian ini berdasarkan ukuran material yang baik dalam pembuatan briket arang adalah lebih besar dari 40 mesh (Ndraha, 2010).

Tabel 1. Formula bahan pembuatan briket

\begin{tabular}{|c|c|c|c|c|}
\hline $\begin{array}{c}\text { Perla- } \\
\text { kuan }\end{array}$ & $\begin{array}{c}\text { Arang } \\
\text { kulit biji } \\
\text { jarak } \\
\text { pagar (g) }\end{array}$ & $\begin{array}{c}\text { Arang } \\
\text { sekam } \\
\text { padi (g) }\end{array}$ & $\begin{array}{c}\text { Perekat } \\
(\mathrm{g})\end{array}$ & $\begin{array}{c}\text { Total } \\
\text { adonan } \\
\text { (g) }\end{array}$ \\
\hline A & 14,25 & 33,25 & 2,5 & 50 \\
\hline B & 11,875 & 35,625 & 2,5 & 50 \\
\hline C & 9,5 & 38 & 2,5 & 50 \\
\hline D & 7,125 & 40,375 & 2,5 & 50 \\
\hline
\end{tabular}

Kemudian disiapkan campuran perekat kanji yang dilarutkan dalam air dengan perbandingan 1:4, selanjutnya dipanaskan. Tepung kanji yang digunakan adalah sebanyak $5 \%$ dari berat campuran arang sekam dan kulit biji jarak pagar. Kadar perekat yang digunakan umumnya tidak lebih dari $5 \%$, karena perekat yang terlalu tinggi dapat mengakibatkan penurunan mutu briket dan menimbulkan banyak asap (Sumangat dan Broto, 2005).

Campuran arang sekam dan kulit biji jarak pagar dicampur dengan perekat kanji sampai membentuk adonan yang tercampur rata. Bahan yang telah tercampur rata ditimbang sebanyak $6 \mathrm{~g}$, kemudian dimasukkan kedalam cetakan yang berbentuk silinder dengan diameter $2 \mathrm{~cm}$ dan tinggi $3 \mathrm{~cm}$, kemudian dilakukan 
pengepresan dengan tekanan $100 \mathrm{~N} / \mathrm{cm}^{2}$. Hasil cetakan dikeringkan dengan sinar matahari selama 2-3 hari.

\section{Analisa Kualitas Briket Arang}

\section{Kadar Air (Metode Oven)}

Cawan porselin bersih dikeringkan dalam oven selama 1 jam pada suhu $105^{\circ} \mathrm{C}$. Setelah itu cawan didinginkan dalam desikator selama 15 menit dan ditimbang. Setelah berat cawan diperoleh, dimasukkan contoh sebanyak 5 gram ke dalam cawan porselin. Cawan porselin yang telah berisi contoh dimasukkan kedalam oven dengan suhu $105^{\circ} \mathrm{C}-110^{\circ} \mathrm{C}$ selama 4 jam. Cawan dikeluarkan dari oven dan dipindahkan ke dalam desikator selama 15 menit kemudian ditimbang untuk selanjutnya dilakukan penghitungan kadar air.

\section{Analisa Kadar Abu (SNI 01-6235-2000)}

Sampel ditimbang sebanyak 5 gram dalam cawan porselin yang telah diketahui beratnya. Masukkan kedalam tanur dengan suhu $600^{\circ} \mathrm{C}$ selama 5 jam sehingga sampel menjadi abu. Kemudian dinginkan dalam desikator selama 15 menit. Timbang dan hitung kadar abu dengan rumus:

$\frac{\text { (berat abu + berat cawan) - berat cawan }}{\text { berat sampel }} \times 100 \%$ Kualitas Nilai Kalor (SNI 01-6235-2000)

Sampel ditimbang sebanyak 1 gram dalam bentuk pelet dan diletakkan dalam cawan platina. Dipasang kawat penyala pada tangkai penyala, kawat penyala bersentuhan dengan bahan yang ada dalam cawan platina. Panjang kawat penyala yang digunakan adalah $10 \mathrm{~cm}$. Kemudian dimasukkan ke dalam tabung bomb yang telah dibersihkan dengan aquades. Tabung ditutup dengan kuat. Dimasukkan oksigen dengan tekanan $35 \mathrm{~atm}$. Tabung bomb ditempatkan dalam kalorimeter yang telah diisi air sebanyak 2 liter dan dihubungkan dengan unit pembakar. Kalorimeter ditutup dengan penutupnya dan termometer dipasang pada tutup kalorimeter. Hubung- kan dengan arus listrik. Amati sampai suhu stabil, setelah stabil catat suhu awal yang ditunjukkan oleh termometer. Pengaduk air pendingin dihidupkan, kemudian amati suhu pada termometer setiap 1 menit. Jika suhu yang ditunjuk oleh termometer sama sebanyak 3 kali berturut-turut maka sumber tegangan arus 23 volt dihidupkan untuk membakar kawat penyala dan sampel. Dicatat kenaikan suhu pada termometer setiap 1 menit. Setelah suhu sama sebanyak 3 kali berturut-turut, sumber tegangan dan pengaduk dimatikan. Buka calorimeter dan keluarkan bomb, buang sisa gas oksigen dari dalam bomb sehingga habis seluruhnya. Bilas permukaan bomb, pindahkan air kedalam gelas ukur. Ukur sisa kawat penyala yang tidak terbakar. Titrasi air bilasan dengan larutan $\mathrm{Na}_{2} \mathrm{CO}_{3}$ dengan menggunakan indikator NO. Dihitung nilai kalor dengan persamaan :

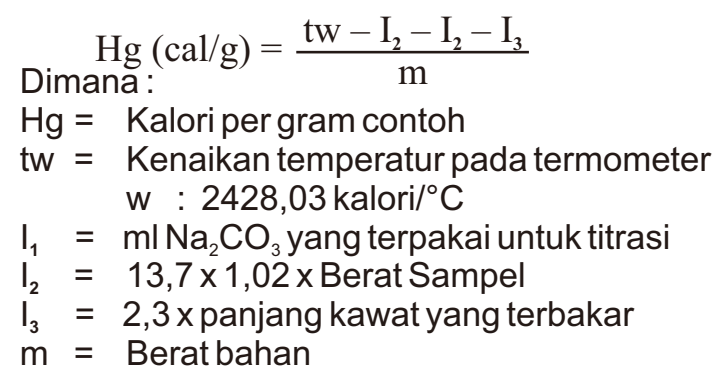

\section{Volatile Matter (SNI 01-6235-2000)}

Cawan porselin yang telah bersih diovenkan pada suhu $105^{\circ} \mathrm{C}$ selama 2 jam. Mendinginkan dalam desikator selama $1 / 2$ jam kemudian ditimbang (A gram). Kedalam cawan porselin ditimbang lebih kurang 1 gram contoh (B gram). Tanurkan pada suhu $900^{\circ} \mathrm{C}$ selama 7 menit, dinginkan dalam desikator selama $1 / 2$ jam kemudian ditimbang (C gram).

Perhitungan :

$$
\% \mathrm{VM}=100-\left(\frac{\mathrm{C}-\mathrm{A}}{\mathrm{B}} \times 100 \%\right)
$$

\section{Fixed Carbon (SNI 01-6235-2000)}

Fixed carbon dihitung dari 100\% dikurangi dengan kadar air lembab (moisture) dikurangi kadar abu, dikurangi kadar zat terbang (volatile matter). 
Perhitungan :

$100 \%$ - (moisture + kadar abu + volatile matter)\%

\section{Kerapatan (Density) (SNI 01-6235-2000)}

Kerapatan dapat dihitung dengan rumus :

$$
\begin{aligned}
\text { Dimana } & =\frac{\mathrm{m}}{\mathrm{V}} \\
\rho & \operatorname{kerapatan}(\mathrm{g} / \mathrm{cm} 3) \\
\mathrm{m} & =\operatorname{massa}(\mathrm{g}) \\
\mathrm{V} & =\operatorname{volume} \text { silinder }\left(\mathrm{cm}^{3}\right)
\end{aligned}
$$

\section{Kekuatan Tekan (SNI 01/6235/2000)}

Uji kuat tekan dilakukan dengan menggunakan force gauge untuk mengetahui kekuatan briket dalam menahan beban dengan tekanan tertentu. Kuat tekan briket dapat dihitung dengan persamaan :

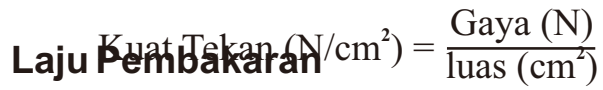

Laju pembakaran briket adalah kecepatan briket habis sampai menjadi abu dengan berat tertentu. Laju pembakaran dapat dihitung dengan menggunakan rumus:

Berat briket $(\mathrm{g})$

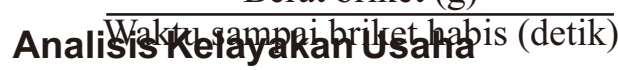

\section{a. Pengeluaran}

Biaya pengeluaran terdiri dari biaya tetap dan biaya tidak tetap (biaya variabel). Biaya tetap merupakan biaya yang dikeluarkan walaupun tidak ada produksi. Yang termasuk biaya tetap umumnya berupa biaya pembelian peralatan. Peralatan tersebut dapat digunakan selama beberapa tahun dalam beberapa kali produksi. Sedangkan biaya variabel merupakan biaya yang dikeluarkan jika ada produksi.

Total biaya produksi $=$ Biaya tetap + Biaya variabel

\section{b. Keuntungan}

$$
\begin{aligned}
& \text { Keuntungan }= \text { Pendapatan }- \text { Total } \\
& \text { biaya produksi }
\end{aligned}
$$

\section{c. Kelayakan Usaha}

Kelayakan usaha dapat ditentukan dengan menghitung Benefit Cost Ratio (B/C). Apabila nilai B/C lebih besar dari 1 maka usulan investasi akan diterima dan dilaksanakan tetapi apabila nilai B/C kurang dari 1 maka dapat diputuskan tidak memenuhi kelayakan atau cenderung rugi.

\section{HASIL DAN PEMBAHASAN}

\section{Analisis Kadar Air Bahan Baku}

Hasil analisis kadar air bahan baku adalah seperti Tabel 2. Kadar air bahan baku sangat menentukan kualitas arang yang dihasilkan. Semakin tinggi kadar air bahan baku maka dalam proses karbonisasi akan lebih banyak kalor yang dibutuhkan untuk mengeluarkan air tersebut menjadi uap sehingga energi yang tersisa dalam arang menjadi lebih kecil (Rahman et al, 2010).

Tabel 2. Nilai rata-rata kadar air bahan baku

\begin{tabular}{llc}
\hline No & Bahan Baku & Kadar air (\%) \\
\hline 1. & Sekam Padi & 7,32 \\
2. & Arang Sekam Padi & 3,41 \\
3. Kulit Biji Jarak Pagar & 10,18 \\
4. & Alemargut KHeridraB i(j1990a) & głangP poglur \\
diperhatikan dalam pengolahan bahan baku \\
adalah kadar air bahan baku. Kadar air \\
material sebelum dilakukan proses pem- \\
briketan tidak lebih dari 12\%. Berdasarkan \\
Tabel 2 dapat dilihat bahwa nilai analisa \\
kadar air dari sekam padi dan kulit biji jarak \\
pagar dibawah 12\%.
\end{tabular}

\section{Analisis Sifat Kimia Briket Arang}

\section{Analisis Kadar Air}

Hasil analisis kadar air seperti pada Tabel 3 menunjukkan bahwa kadar air semakin rendah jika jumlah arang kulit biji jarak pagar semakin banyak. Hal ini diduga 
karena perbedaan luas permukaan bahan pembuat briket tersebut sehingga mempengaruhi jumlah kadar air. Sesuai dengan pernyataan Supriyono (2003) bahwa luas permukaan bahan yang besar memungkinkan terjadinya penguapan kadar air lebih cepat dibandingkan dengan bahan yang luas permukaannya lebih kecil.

Tabel 3. Nilai rata-rata kadar air briket arang

\begin{tabular}{ll}
\hline Perlakuan & \multicolumn{2}{l}{ Kadar Air (\%) } \\
\hline D $(15 \%: 85 \%)$ & 15,607 a \\
C $(20 \%: 80 \%)$ & 12,910 b \\
B $(25 \%: 75 \%)$ & $7,4200 \quad \mathrm{C}$ \\
A $(30 \%: 70 \%)$ & $6,7367 \quad$ d \\
\hline
\end{tabular}

KK KKadar Qji68angat erat kaitannya dengan kerapatan briket arang, dimana semakin tinggi kerapatan maka sifat higroskopis briket arang semakin berkurang sehingga daya serap terhadap air akan semakin kecil, demikian pula sebaliknya. Hal ini disebabkan semakin tinggi kerapatan maka rongga-rongga antar partikel arang akan semakin rapat karena padunya partikelpartikel tersebut sehingga tidak terdapat celah atau ruang kosong (Bahri, 2007).

\section{Analisis Kadar Abu}

Kadar abu semakin besar jika jumlah arang sekam padi semakin banyak. Hal ini diduga karena jumlah silika yang dikandung oleh sekam padi. Menurut Hendra dan Darmawan (2000) dalam Bahri (2008), salah satu unsur kadar abu adalah silika dan pengaruhnya kurang baik terhadap nilai kalor yang dihasilkan. Kadar abu yang tinggi juga disebabkan oleh jumlah kadar abu pada bahan pembuat briket. Kadar abu kulit biji jarak pagar menurut Syah (2006) adalah $2,8 \%-6,1 \%$ sedangkan kadar abu sekam padi menurut Suharno dalam Nugraha dan Setiawati (2001) adalah sebesar $17,71 \%$.

Kadar abu yang didapatkan tidak ada yang memenuhi SNI 01-6235-2000 seperti terlihat pada Tabel 4. Hal ini diduga karena komposisi bahan baku yang mengandung abu, serat, protein, lemak dan karbohidrat yang menjadi abu pada saat proses pengabuan.

Tabel 4. Nilai rata-rata kadar abu briket arang

\begin{tabular}{lc}
\hline Perlakuan & Kadar Abu (\%) \\
\hline D $(15 \%: 85 \%)$ & 8,93 a \\
C $(20 \%: 80 \%)$ & 8,49 a \\
B $(25 \%: 75 \%)$ & 8,19 a \\
A $(30 \%: 70 \%)$ & 6,07 b \\
\hline
\end{tabular}

Anala

Hasil analisis kualitas nilai kalor adalah seperti Tabel 5. Menurut Hartoyo (1983) dalam Ndraha (2010) bahwa kualitas nilai kalor briket yang dihasilkan dipengaruhi oleh nilai kalor atau energi yang dimiliki oleh bahan penyusunnya. Nilai kalor sekam padi menurut Warta Penelitian dan Pengembangan Pertanian (2008) adalah 3.300-3600 $\mathrm{kkal} / \mathrm{kg}$ sedangkan jumlah energi kulit biji jarak pagar menurut Syah (2006) adalah 19,3-19,5 MJ/kg.

Tabel5. Nilai rata-rata kualitas nilai kalor briket arang

\begin{tabular}{lc}
\hline Perlakuan & Kualitas Nilai Kalor (\%) \\
\hline A $(30 \%: 70 \%)$ & 3906,27 a \\
B $(25 \%: 75 \%)$ & 3899,12 a \\
C $(20 \%: 80 \%)$ & 3519,05 b \\
D $(15 \%: 85 \%)$ & $3297,24 \quad \mathrm{c}$ \\
\hline
\end{tabular}

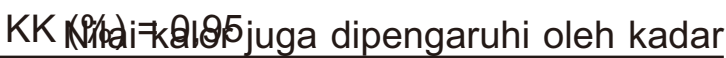
air dan kadar abu yang ada dalam briket arang, semakin rendah kadar air dan kadar abu dalam briket arang maka akan meningkatkan nilai kalor briket arang yang dihasilkan. Sesuai dengan pernyataan Nurhayati (1974) dalam Bahri (2008), bahwa nilai kalor dipengaruhi oleh kadar air dan kadar abu yang ada pada briket arang. Apabila semakin tinggi kadar air dan kadar abu, maka nilai kalor yang dihasilkan rendah.

Menurut Sudrajat (1984) dalam Bahri (2008) nilai kalor juga erat kaitannya dengan kerapatan briket arang. Jika semakin tinggi kerapatan maka cendrung akan meningkatkan nilai kalor karena ikatan antar partikel arang yang lebih kuat sehingga akan menghasilkan panas yang lebih baik.

\section{Analisis Volatile Matter}


Hasil analisis volatile matter briket arang kulit biji jarak pagar dan sekam padi rata-rata diatas SNI 01-6235-2000 seperti pada Tabel 6 . Menurut Hendra dalam Sinurat (2011) tinggi rendahnya volatile matter yang dihasilkan dipengaruhi oleh jenis bahan baku, sehingga perbedaan jenis bahan baku berpengaruh nyata pada nilai volatile matter tiap briket arang.

Tabel6. Nilai rata-rata volatile matter briket arang

\begin{tabular}{lc}
\hline Perlakuan & Volatile Matter (\%) \\
\hline $\mathrm{A}(30 \%: 70 \%)$ & $14,88 \mathrm{a}$ \\
$\mathrm{C}(20 \%: 80 \%)$ & $15,11 \mathrm{a}$ \\
$\mathrm{B}(25 \%: 75 \%)$ & $14,31 \mathrm{a}$ \\
$\mathrm{D}(15 \%: 85 \%)$ & $12,83 \mathrm{~b}$ \\
\hline
\end{tabular}

KK \$̊\% hākir $29_{\text {banyak kandungan volatile }}$ matter pada briket maka briket tersebut akan semakin mudah untuk terbakar dan menyala (Samsul dalam Sinurat, 2011). Volatile matter dalam bahan bakar berfungsi untuk menstabilkan nyala dan percepatan pembakaran arang.

Kadar zat menguap ditentukan oleh kesempurnaan proses karbonisasi. Disamping itu kadar zat menguap juga dipengaruhi oleh suhu dan waktu pengarangan, semakin besar suhu pada waktu pengarangan maka semakin banyak zat menguap yang terbuang selama proses pengarangan sehingga kandungan zat menguap akan semakin kecil (Tampubolon (2001) dalam Bahri (2007)).

\section{Analisis Fixed Carbon}

Dari hasil analisis yang dilakukan, dapat dilihat bahwa kadar fixed carbon briket arang kulit biji jarak pagar dengan sekam padi masih dibawah SNI 01-6235-2000 seperti Tabel 7.

Menurut Sinurat (2011) keberadaan Fixed Carbon di dalam arang dipengaruhi oleh nilai kadar abu dan zat menguap. Kadar fixed carbon akan bernilai tinggi apabila kadar abu dan volatile matter rendah.

Tabel 7. Nilai rata-rata kadar fixed carbon briket arang

\begin{tabular}{lll}
\hline Perlakuan & \multicolumn{2}{c}{ Fixed Carbon $(\%)$} \\
\hline B $(25 \%: 75 \%)$ & 73,45 & a \\
C $(20 \%: 80 \%)$ & 73,35 & a \\
A $(30 \%: 70 \%)$ & 72,32 & a \\
D $(15 \%: 85 \%)$ & 72,27 & a \\
\hline
\end{tabular}

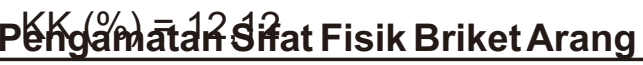

\section{Kerapatan (Density)}

Hasil pengamatan kerapatan rata-rata diatas nilai SNI 01-6235-2000 seperti Tabel 8. Kerapatan berpengaruh terhadap kualitas briket arang, karena dengan kerapatan yang tinggi dapat meningkatkan nilai kalor briket arang. Besar kecilnya kerapatan dipengaruhi oleh ukuran dan kehomogenan arang penyusun briket arang tersebut. Menurut Nurhayati (1983) dalam Bahri (2008), semakin tinggi keseragaman ukuran serbuk arang maka akan menghasilkan briket arang dengan kerapatan dan keteguhan yang semakin tinggi.

Tabel 8. Nilai rata-rata kerapatan (density) briket arang

\begin{tabular}{lcc}
\hline Perlakuan & \multicolumn{2}{c}{ Kerapatan $\left(\mathrm{gr} / \mathrm{cm}^{3}\right)$} \\
\hline A $(30 \%: 70 \%)$ & 0,81 & a \\
B $(25 \%: 75 \%)$ & 0,78 & ab \\
C $(20 \%: 80 \%)$ & 0,77 & ab \\
D $(15 \%: 85 \%)$ & 0,74 & b \\
\hline
\end{tabular}

KK \&\& $\%$ dräjat 05 1983) menyatakan bahwa bahan baku yang berkerapatan tinggi cenderung menghasilkan briket arang dengan kerapatan yang tinggi, ini disebabkan oleh kandungan serat yang lebih rapat pada bahan penyusun briket. Hal ini dapat dilihat bahwa semakin tinggi komposisi arang sekam padi, maka kerapatan briket arang yang dihasilkan semakin rendah. Anonimous (2008) menyebutkan bahwa kerapatan sekam padi yaitu $0,1 \mathrm{~g} / \mathrm{cm}^{3}$. Sedangkan dalam penelitian Sudrajat dkk (2005) briket dengan komposisi 100\% tempurung biji jarak pagar menghasilkan kerapatan yang tinggi, yaitu $0,19-0,21 \mathrm{~g} / \mathrm{cm}^{3}$.

\section{Kekuatan Tekan}


Hasil analisa kekuatan tekan pada Tabel 9 rata-rata dibawah nilai SNI 01-62352000. Menurut Nurhayati (1983) cit Bahri (2008), ukuran serbuk arang yang semakin seragam akan mempengaruhi keteguhan tekan dan kerapatan briket arang. Tingginya keteguhan tekan briket arang yang dihasilkan disebabkan oleh ukuran serbuk arang yang cendrung lebih seragam.

Tabel 9. Nilai rata-rata kekuatan tekan briket arang

\begin{tabular}{lcc}
\hline Perlakuan & Kekuatan Tekan $\left(\mathrm{N} / \mathrm{cm}^{2}\right)$ \\
\hline A $(30 \%: 70 \%)$ & 15,30 & a \\
B $(25 \%: 75 \%)$ & 13,03 & b \\
C $(20 \%: 80 \%)$ & 11,87 & $\mathrm{C}$ \\
D $(15 \%: 85 \%)$ & 11,43 & $\mathrm{C}$ \\
\hline
\end{tabular}

$\mathrm{KK} \$ \%$ elaī $1_{i t u} \mathrm{O}_{\text {keteguhan tekan juga dipe- }}$ ngaruhi oleh ukuran serbuk arang. Hartoyo (1983) dalam Bahri (2008) menjelaskan bahwa ukuran partikel serbuk arang yang terlalu halus menghasilkan briket arang yang keteguhan tekannya lebih rendah dibandingkan dengan briket arang yang terbuat dari ukuran partikel serbuk arang yang lebih besar.

\section{Laju Pembakaran}

Hasil pengamatan laju pembakaran briket arang seperti Tabel 10. Menurut Syamsiro dan Saptoadi (2007) Iaju pembakaran biobriket paling cepat adalah pada komposisi biomassa yang memiliki banyak kandungan volatile matter (zat-zat yang mudah menguap). Semakin banyak kandungan volatile matter briket maka semakin mudah briket tersebut terbakar, sehingga laju pembakaran semakin cepat.

Kecepatan pembakaran juga dipengaruhi struktur bahan, kadar karbon terikat, keras dan lunaknya bahan meskipun secara teori jika kadar volatilnya tinggi maka akan mudah terbakar dan kecepatan pembakaran lebih tinggi (Jamilatun, 2011).

Tabel 10. Nilai rata-rata laju pembakaran briket arang

\begin{tabular}{lrc}
\hline Perlakuan & $\begin{array}{c}\text { Laju Pembakaran } \\
\text { (g/menit) }\end{array}$ \\
\hline B $(25 \%: 75 \%)$ & 1,96 a \\
C $(20 \%: 80 \%)$ & 1,38 & $\mathrm{~b}$ \\
A $(30 \%: 70 \%)$ & 1,16 & $\mathrm{C}$ \\
D $(15 \%: 85 \%)$ & 0,87 & $\mathrm{~d}$ \\
\hline
\end{tabular}

\section{Añalis}

Faktor ekonomis merupakan faktor terpenting dalam suatu perancangan produk dan diharapkan biaya yang dikeluarkan seminimimal mungkin. Elemen biaya yang harus diperhatikan adalah :

Asumsi :

- Sampel adalah A dengan perbandingan $30 \%$ arang kulit biji jarak pagar dan $70 \%$ arang sekam padi.

- Rendemen kulit biji jarak pagar menjadi arang sebesar $40 \%$ $=(100 / 40) \times 0,3 \mathrm{~kg}=0,75 \mathrm{~kg}$

- Rendemen sekam padi menjadi arang sebesar $35 \%$

$=(100 / 35) \times 0,7 \mathrm{~kg}=2 \mathrm{~kg}$

1. Biaya Tetap

Alat-alat pembuatan briket

$$
=\operatorname{Rp} 13.970 .000,-
$$

Nilai akhir alat $(\mathrm{S}) \quad=\quad 10 \%$ dari harga awal

$$
\begin{aligned}
& =13.970 .000 \times 10 \% \\
& =\operatorname{Rp} 1.397 .000,-
\end{aligned}
$$

Umur ekonomi alat $(\mathrm{n})=2$ tahun

2. Biaya Variabel

Biaya bahan baku

- Kulit biji jarak pagar @Rp 100/kg $\mathrm{Rp} 75 / \mathrm{kg}$

- Sekam padi@Rp50/kg Rp 100/kg

- Tepung kanji/Kg Rp3.000

- Air $/ \mathrm{m}^{3} \quad \operatorname{Rp} 1.000$

- Listrik/kilowatt Rp100

- Kayu bakar/ikat Rp 1.000

- Bahan bakar/Kg Rp 5.000

- Kemasan/bungkus Rp 10 Total

Rp 10.285

3. Biaya Tenaga Kerja

Upah tenaga kerja/hari Rp 20.000

Upah tenaga kerja/jam Rp 2.500

Jam kerja : 7 jam/hari, 25 hari/bulan, 300 
hari/tahun.

Waktu pembuatan produk menit

4. Produksi/hari $\quad: 50 \mathrm{~kg}$

5. Tenaga kerja :2 orang

6. Biaya perawatan dan perbaikan alat : $13,5 \%$ dari harga awal

7. Tingkat bunga modal dan asuransi (i) : $15 \% /$ tahun

8. Biaya sewa bangunan : 1.000.000.Itahun

9. Pajak alat dan mesin $\quad: 1 \%$ dari harga awal

\section{Perhitungan biaya}

Nilai Benefit Cost Ratio > 1 (besar dari 1), dapat disimpulkan bahwa usaha pembuatan briket arang ini layak untuk dikembangkan seperti terlihat pada Tabel 11.

Dari hasil perhitungan Break Even Point diketahui bahwa jika produsen mampu menjual 11.538,463 kg/tahun maka titik impas akan tercapai.

Tabel. 11 Total penghitungan biaya

\begin{tabular}{cll}
\hline No. & Jenis Biaya & \multicolumn{1}{c}{ Total } \\
\hline 1. & Biaya Tetap & $\operatorname{Rp~8.997.825.-/tahun~}$ \\
2. & Biaya Variabel & $\operatorname{Rp~37.474.950.-/tahun~}$ \\
3. & Biaya Produksi & $\operatorname{Rp~154.909,25.-/hari~}$ \\
4. & Keuntungan & $\operatorname{Rp~46.472,75.-/hari~}$ \\
5. & Benefit Cost Ratio & $\operatorname{Rp~1,3}$ \\
6. & Break Even Point & $\operatorname{Rp~11.538,463~kg/tahun~}$ \\
\hline
\end{tabular}

\section{KESIMPULAN DAN SARAN}

\section{Kesimpulan}

Berdasarkan hasil penelitian yang telah dilaksanakan maka dapat diambil kesimpulan sebagai berikut:

1. Perbedaan perlakuan komposisi pembuatan briket arang memberikan pengaruh terhadap uji kadar air, kadar abu, kualitas nilai kalor, volatile matter, fixed carbon, kerapatan dan kekuatan tekan yang dilakukan.

2. Dari 4 perlakuan yang diujikan, yang terbaik ditinjau dari segi nilai kalor adalah perlakuan $30 \%$ arang kulit biji jarak pagar $+70 \%$ arang sekam padi.

3. Peningkatan penambahan persentase serbuk arang sekam padi akan menurunkan kekuatan tekan, meningkatkan kadar air dan kadar abu.
4. Hasil analisis sifat kimia dan fisik briket arang dari sekam padi dan kulit biji jarak pagar rata-rata belum memenuhi SNI 01-6235-2000 briket arang kayu.

5. Briket arang ini layak untuk dikembangkan dari segi analisa kelayakan usahanya.

\section{Saran}

Perlu dilakukan penelitian lebih lanjut mengenai campuran briket arang dengan bahan baku lain untuk menghasilkan kualitas briket yang lebih baik.

\section{DAFTAR PUSTAKA}

Anonimous. 2008. Energi Mahal, Manfaatkan Briket Arang Sekam. Warta Penelitian dan Pengembangan Pertanian, Vol. 30 No. 4.

Badan Pusat Statistik. 2011. Produksi Padi dan Potensi Sekam di Indonesia.

Badan Standardisasi Nasional. 2000. Standar Nasional Indonesia Briket arang kayu. SNI 01-6235-2000.

Bahri, S. 2008. Pemanfaatan Limbah Industri Pengolahan Kayu Untuk Pembuatan Briket Arang dalam Mengurangi Pencemaran Lingkungan di Nangroe Aceh Darussalam, Tesis, USU e-Repository 2008.

Hartoyo. 1983. Pembuatan Arang dari Briket Arang Secara Sederhana dari Serbuk Gergaji dan Limbah Industri Perkayuan. Puslitbang Hasil Hutan Bogor.

Hendra, D. 1999. Bahan Baku Pembuatan Arang dan Briket Arang, Pusat Penelitian dan Pengembangan Hasil Hutan, Gunung Batu Bogor.

Hendra, D., \& S. Darmawan. 2000. Pembuatan Briket Arang Serbuk Gergajian Kayu dengan Penambahan Tempurung Kelapa. Buletin Penelitian Hasil Hutan. Bogor 18(1):pp 1-9.

Hermawan, Y. 2005. Pemanfaatan Limbah Sekam Padi Sebagai Bahan Bakar Dalam Bentuk Briket, Jurusan Teknik 
Mesin Fakultas Teknik Universitas Jember.

Jamilatun, S. 2011. Kualitas Sifat-sifat Penyalaan dari Pembakaran Briket Tempurung Kelapa, Briket Serbuk Gergaji Kayu Jati, Briket Sekam Padi dan Briket Batubara, Prosiding Seminar Nasional Teknik Kimia "Kejuangan" Pengembangan Teknologi Kimia untuk Pengolahan Sumber Daya Alam Indonesia, Program Studi Teknik Kimia, Universitas Ahmad Dahlan Yogyakarta.

Ndraha, N. 2010. Uji Komposisi Bahan Pembuat Briket Bioarang Tempurung Kelapa dan Serbuk Kayu Terhadap Mutu Yang Dihasilkan, Skripsi, Fakultas Pertanian Universitas Sumatera Utara, Medan.

Nugraha, S., \& Setiawati, J. 2001. Peluang Agribisnis Arang Sekam, Balai Penelitian Pascapanen Pertanian Departemen Pertanian, Jakarta.

Nurhayati, T. 1984. Catatan Singkat Tentang Kualitas Arang Kayu Sehubungan dengan Kegunaannya. Majalah Kehutanan Indonesia. Vol.1 Jakarta.

Rahman, B. N., Onu, F., \& Sudarjo. 2010. Pengukuran Nilai Kalor Bahan Bakar Briket Arang Kombinasi Cangkang Pala (Myristica Fragan Houtt) dan Limbah Sawit (Elaeis Guenensis). Seminar Nasional Teknik Mesin Universitas Muhammadiyah Yogyakarta. Hal. 104115.

Sinurat, E. 2011. Studi Pemanfaatan Briket Kulit Jambu Mete dan Tongkol Jagung Sebagai Bahan Bakar Alternatif, Skripsi, Jurusan Mesin Fakultas Teknik Universitas Hasanuddin, Makassar.

Sipahutar, D. 2011. Teknologi Briket Sekam Padi, Balai Pengkajian Teknologi Pertanian (BPTP), Riau.

Sudrajat, R. 1984. Pengaruh Kerapatan Kayu, Tekanan Pengempaan dan Jenis Perekat terhadap Sifat Briket Kayu. Jurnal Penelitian Hasil Hutan Bogor. 1(1): 11-15.
Sudradjat, R. Setiawan, D., dan Roliadi, H. 2005. Teknik Pembuatan dan Sifat Briket Arang dari Tempurung dan Kayu dari Tanaman Jarak Pagar (Jatropha curcas L.). Pusat Penelitian Hasil Hutan Bogor.

Sumangat, D., \& Broto, W. 2005. Kajian Teknis dan Ekonomis Pengolahan Briket Bungkil Biji Jarak Pagar Sebagai Bahan Bakar Tungku, Buletin Teknologi Pascapanen Pertanian, "Vol. 5", Hal. 18-26.

Supriyono. 2003. Mengukur Faktor-faktor dalam Pengeringan. Bagian Pengembangan Kurikulum Direktorat Pendidikan Menengah Kejuruan Direktorat Jendral Pendidikan Dasar dan Menengah Departemen Nasional, Jakarta.

Syah, A.N.A. 2006. Mengenal Lebih Dekat Biodiesel Jarak Pagar, Jakarta : PT. Agro Media Pustaka

Syakir, M. 2010. Prospek dan Kendala Pengembangan Jarak Pagar (Jatropha Curcas L.) Sebagai Bahan Bakar Nabati di Indonesia, Jurnal Perspektif, Pusat Penelitian dan Pengembangan Perkebunan, Bogor, "Vol. 9 No. 2", Hal. 55-65.

Syamsiro, M., \& Saptoadi, H. 2007. Pembakaran Briket Biomassa Cangkang Kakao : Pengaruh Temperatur Udara Preheat, Seminar Nasional Teknologi 2007 (SNT 2007), Yogyakarta.

Tampubolon, D. 2001. Pembuatan Briket Arang Kotoran Sapi Perah dengan Penambahan Tempurung Kelapa. Skripsi. Jurusan IImu Produksi Ternak Fakultas Peternakan Institut Pertanian Bogor.

Working Group Bidang Energi. 2008. Lokakarya Agenda Riset Bidang Pangan dan Energi, Agenda Riset Energi, Institut Pertanian Bogor, Bogor 